\title{
高圧水銀ランプ連続調光式点灯回路の電力変動低減化
}

$\begin{array}{llll}\text { 非会員 } & \text { 黒住 } & \text { 正明* } & \text { 非会員 家村 拓雄** } \\ \text { 非会員 鷲宮 } & \text { 秀幸*** } & \text { 正 員 家村 道雄*** }\end{array}$

\section{A Method of Reducing Fluctuations of Lamp Power in a Continuous Dimmer Circuit for High-Pressure Mercury Discharge Lamps}

Masaaki Kurozumi*, Non-member, Takuo Iemura**, Non-member, Hideyuki Wasimiya***, Non-member, Michio Iemura***, Member

In order to reduce fluctuations of lamp power and maintain constant power in a continuous dimmer circuit in high-pressure mercury discharge lamps, the authors propose to add a supplementary control circuit on the continuous dimmer circuit. This supplementary control circuit is equipped with a photosensor to control the levels of light.

Moreover, we connect the by-pass circuit to the tap of ballast which is close to the power source side. The addition of a by-pass circuit, in which circuit constant is adjusted to reasonable value, make it possible to improve power factor and reduce harmonic current.

キーワード : 連続調光式点灯回路，バイパス回路，正弦波電流，電力変動，高調波電流

Keywords : continuous dimmer circuit, by-pass circuit, sinusoidal wave currentf, luctuation of power, harmonic currents

\section{1. まえがき}

高圧水銀ランプ一般形点灯回路の調光方式として, 段調 光方式が省エネルギー化の目的で道路，公園あるいは工場 の照明用に用いられている。この方式は安定器のインピー ダンスをリレー制御により 2 段階で加減し，定格とその約 $60 \%$ の 2 通りの消費電力で点灯する。この方式による安定 器の入力電流のひずみ率は 10～15\% と大きく，電源電圧の 波形に悪い影響(ひずみ)を与えることになる。

筆者らは高圧水銀ランプ連続調光式点灯回路の安定器巻 線途中にバイパス回路を接続することで高調波電流低減化

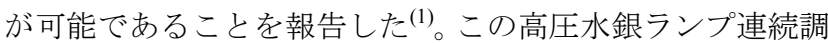
光式点灯回路は, 電源側の電圧が変動するとランプ電力が 著しく変動する特性がある。さらに, 調光をかけ，ランプ 電力を低くして使用した状態で電源電圧を変動させるとラ ンプ電力の変動がさらに大きくなり，ランプの立ち消えが

\footnotetext{
* 宮崎県教育研修センター

干880-0835 宮崎市阿波岐原町前浜 4276-729

Miyazaki Prefectural Education Center

4276-729 Maehama Awakigahara, Miyazaki 880-0835

** (株)九電工東京支店

干170-6035 東京都豊島区東池袋 3-1-1 サンシャイン 6035 階 Kyudenkou, Co, Ltd

3-1-1 Higasi Ikebukuro Toshima-ku,Tokyo 170-6035

*** 崇城大学 (旧名: 熊本工業大学)

干860-0082 熊本市池田 4-22-1

Sojo University

4-22-1, Ikeda, Kumamoto 860-0082
}

発生する。

本論文では, 上記提案の回路構成の問題を踏まえて, 連 続調光回路に光センサーを用いた光量補正制御回路を付加 し，ランプ電力の変動を補正することにより連続調光回路 の電力変動低減化と立ち消えの発生を抑えることを可能と する。本回路方式により, ランプ電力の変動を抑えた状態 で電源側高調波電流を著しく低減させ, 力率もほぼ $100 \%$ に 近づける。すなわち, 連続調光式点灯回路の電力変動低減 化と高調波電流低減化及び力率改善法を定格ランプ電力 200Wの点灯回路で示す。

\section{2. 電力変動低減形連続調光式点灯回路}

高圧水銀ランプ連続調光式制御回路を図 1 に示す ${ }^{(2)}$ 。 連続調光式点灯回路により，導通角を調整することでラ ンプ電力を制御すると電源電圧の変動によるランプ電力の 変動が遅相形点灯回路と比べて 2 倍近く大きくなる特性を 示す。このため安定した調光がなされたとは言えない。ま た連続調光式点灯回路は立ち消えを起こし易い回路である ため, 一般的には図 1 のように制御素子であるトライアッ クと並列にコイル $\mathrm{L}_{\mathrm{t}}$ を入れ，防いでいる。しかし，制御回 路の小型化, 低コスト化の面からは好ましくない。この連 続調光式点灯回路の電力変動の低減及び立ち消えの発生を 防ぐ方法として, 調光回路に導通角を光センサーにより補 正制御する回路を加える。図 2 に光量補正制御回路を付加 


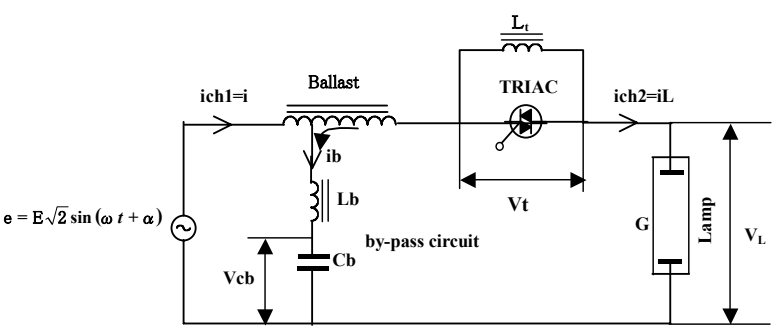

図 1 高圧水銀ランプ連続調光式制御回路

Fig. 1. Continuous dimmer circuit with TRIAC for a high-pressure mercury arc lamp.
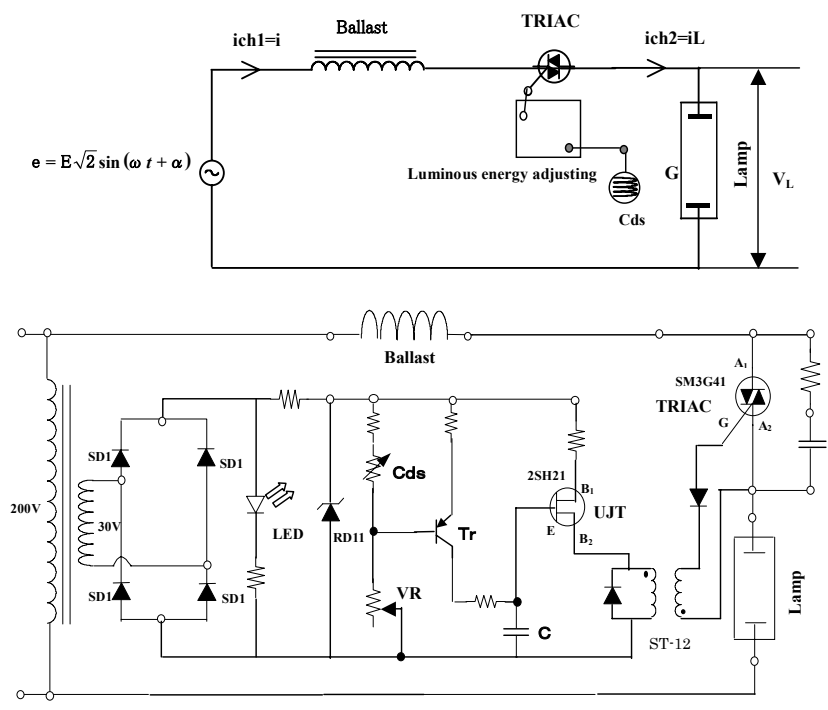

図 2 電力変動低減形高圧水銀ランプ連続調光式 制御回路（バイパス回路なし）

Fig. 2. Continuous dimmer circuit with TRIAC which reduces fluctuation of lamp power for a high-pressure mercury arc lamp (non-by-pass circuit).

した電力変動低減形連続調光式点灯回路を示す。電源電圧 の上昇と共にランプ電圧が上昇し, 光量が増すと光センサ 一である Cds の抵抗值が小さくなる。ベース・ブリーダ抵 抗となる可変抵抗 VR の電圧が上昇するため, コンデンサへ の充電電流であるトランジスタのコレクタ電流が減少す る。よって充電に要する時間が長くなることで UJT 移相回 路のパルス間隔が広がり，トライアックの導通角が小さく なるように補正制御がかかるため，ランプ電流を減じて暗 くする方向に電力変動を低減する。また電源電圧が降下し, 光量が減少した場合は，上記と逆の制御がかかり，UJT 移 相回路のパルス間隔が狭くなり, トライアックの導通角が 大きくなるように補正制御がかかるため, ランプ電流を増 加させ明るくする方向に電力変動を低減する。よって立ち 消えの発生に対しても防ぐ方向で常に制御がかかるため, 立ち消えを起こしにくい回路となる。すなわち調光回路を 電力変動低減形とすることで遅相形点灯回路同等以上の低 変動特性を得ることができる。電力変動を低減する手法と して他の制御方式も考えられるが, 安定した光量を得る観

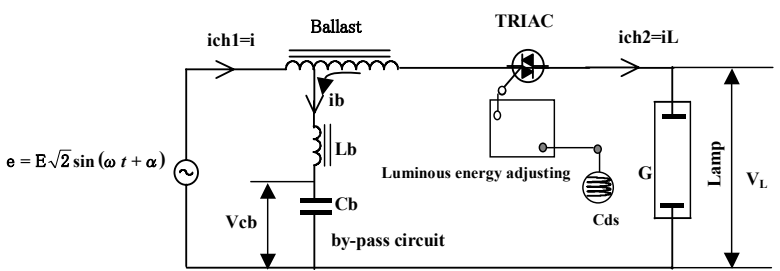

図 3 電力変動低減形高圧水銀ランプ連続調光式 制御回路

Fig. 3. Continuous dimmer circuit with TRIAC which reduces fluctuation of lamp power for a high-pressure mercury arc lamp.

点から，本手法を用いた。しかし，この制御回路は新たに 高調波電流等の発生原因ともなり, 電源電圧波形のひずみ 率を悪化させる。そこで本論文では, 図 3 のようにこの制 御回路を安定器巻線のランプ側に置き, 制御回路の電源も 含めた状態でさきに報告している安定器巻線途中にバイパ ス回路を接続することで同時に高調波電流低減化も可能と した。

\section{3. 実験方法}

筆者らは，さきに連続調光式点灯回路においてのシミュ レーション方法を報告している(2)。連続調光式点灯回路では 安定状態でシミュレーションを行った。電力変動低減形連 続調光式点灯回路では光量によるフィードバック制御がか かるため, 以下のようにシミュレーションで求めた回路定 数をもとに, 電源電圧として $200 \mathrm{~V} 60 \mathrm{~Hz}$ の正弦波電圧を印 加し実験により考察する。電源には非正弦波電流が流れて もほぼ正弦波電圧を発生する電力増幅器を用いた。

実験は，高圧水銀ランプ連続調光式点灯回路と高圧水銀 ランプ電力変動低減形連続調光式点灯回路の 2 つの回路に おいて, 比較検討を行う。

調光状態としては, 定格電圧 $200 \mathrm{~V}$ において導通角がほぼ $180^{\circ}$ のランプ電力が最大となる時と, 導通角を調節してラ ンプ電力が $175 \mathrm{~W}, 150 \mathrm{~W}, 125 \mathrm{~W}, 100 \mathrm{~W}$ となるように調光を行 う。この 5 つの調光状態の下で電源電圧を $180 \mathrm{~V} \sim 220 \mathrm{~V}$ まで $5 \mathrm{~V}$ 間隔で変化させる。

それぞれの電力に調光した場合について, 電源電圧の変 動に対するランプ電力の変動を求め, さらに力率, 電源電 流のひずみ率などを調べる。

〈3·1〉連続調光式点灯回路にバイパス回路を設けた場 合図 1 に示寸ように, 安定器巻線の途中に高調波電流 を低減するためのバイパス回路を設けた回路で $L_{t}$ を除いた 状態で実験を行う。定格ランプ電力 $200 \mathrm{~W}$ 点灯回路の安定器 巻線の定格インダクタンスの值はほぼ $L=0.194 \mathrm{H}$ で, 安定器 巻線途中からバイパス回路を設けて力率を 1 に近づけるた めに, $\mathrm{Cb}$ の值を大きくするとバイパス回路の基本波インピ 一ダンスが小さくなり，ランプの基本波インピーダンスも 小さくなる。そのためランプの電流が大きくなりすぎる。 すなわち, $L=0.194 \mathrm{H}$ で, バイパス回路を設けるとランプの 


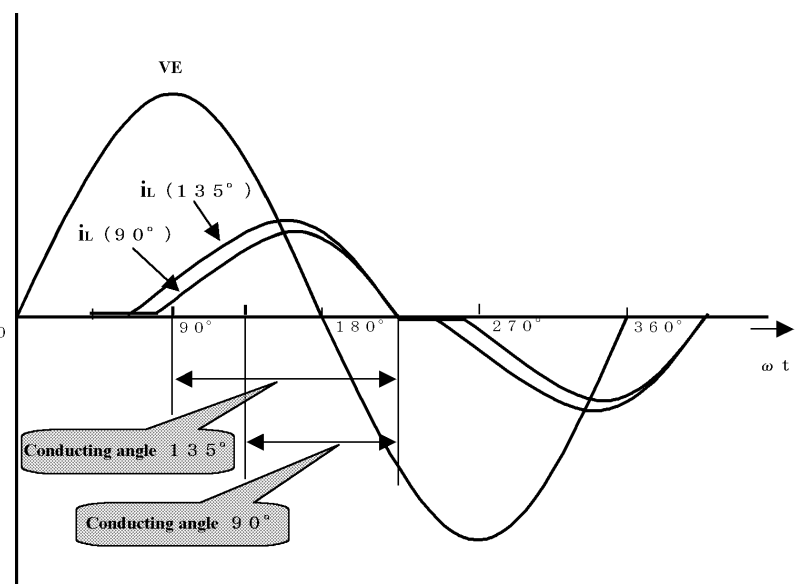

図 4 導通角 $135^{\circ}, 90^{\circ}$ 調節例

Fig. 4. Examples of $135^{\circ}$ and $90^{\circ}$ conducting angle.

電流，電力を JIS 規格内に保つことができない。そこで， $L$ を大きくする必要がある。 $L=0.26 \mathrm{H}$ で電源側より $1 / 5$ タップ 位置にバイパス回路を設けると電源電流のひずみ率を $3 \%$ 以内に改善でき, ランプ電流, 電力を JIS 規格内に保つこと が可能である。ランプに流れる高調波電流は, 第 3 調波電 流が最も大きいので，バイパス回路の $L b$ と $C b$ の回路定数 は第 3 調波 $(3 \times 60 \mathrm{~Hz})$ をバイパス回路の共振周波数とし，シ ミュレーションにより求める。本実験ではシミュレーショ ンで求められた $L b$ の值に近い $75 \mathrm{mH}$ のコイルを使用した。 さらに，次式から $C b$ を算出する。

$$
(L b-M)=\frac{1}{(3 \times 2 \pi \times 60)^{2} \cdot C b}
$$

ただし， $M$ は $L$ のタップより電源側, ランプ側の

それぞれのインダクタンスの相互インダクタンス 電源電流のひずみ率が小さくなり，電力最大時において定 格電圧で電源側に力率がほぼ $100 \%$ の正弦波電流が流れる ための $C b$ の值を微調節する。ここで, 最適な $C b$ の值は 19.9 $\mu \mathrm{F}$ であった。

実験は，まず導通角を最大にして電源電圧として $200 \mathrm{~V}$ $60 \mathrm{~Hz}$ の正弦波電圧を印加する。ランプが安定状態に到達後, 電源電圧を $180 \mathrm{~V} \sim 220 \mathrm{~V}$ まで $5 \mathrm{~V}$ 間隔で徐々に上げていく。 それぞれの電圧においてランプ側の電力, 電圧, 電流, そ して電源側の電力, 電流, さらに電源側の力率や電源電流 のひずみ率を求める。また，ランプ電力を $175 \mathrm{~W} \sim 100 \mathrm{~W}$ に 調節した状態で同様に測定を行った。

下記に示される図 5 が, 連続調光回路の電源電圧の変動 に対するランプ電力の変化を示したものである。

図 5 からもわかるように, 電源電圧の変動に対するラン プ電力の変動が大きく, 電源電圧低下により, 導通角を小 さく調光するほど点灯を持続することができない。

\section{$\langle 3 \cdot 2\rangle$ 電力変動低減形連続調光式点灯回路のみの場合}

図 2 のように, 電力変動低減形連続調光式点灯回路の場 合も同様に実験を行っていく。

安定器巻線は $194 \mathrm{mH}$ を使用する。また, 光センサーは光 量の変化に対する感度が高いランプとの距離 $50 \mathrm{~cm}$ をとり

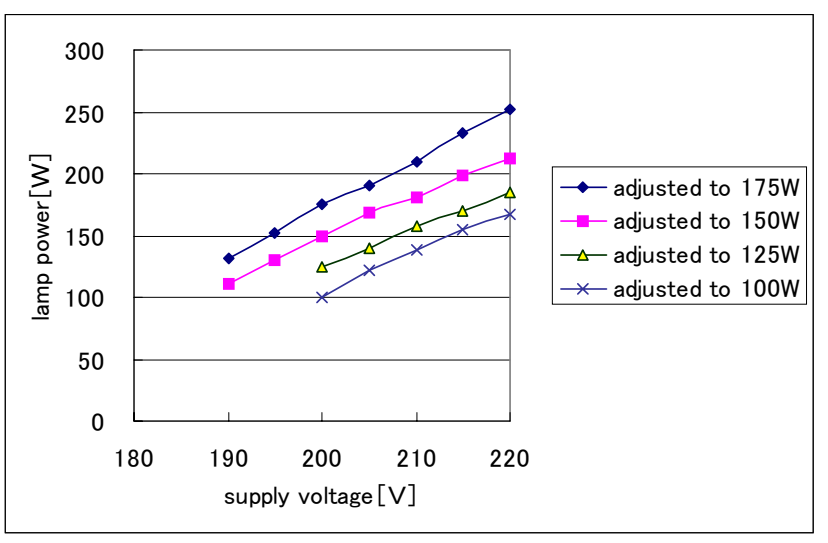

図 5 電源電圧に対するランプ電力の特性

Fig. 5. Characteristics of lamp power for voltage.

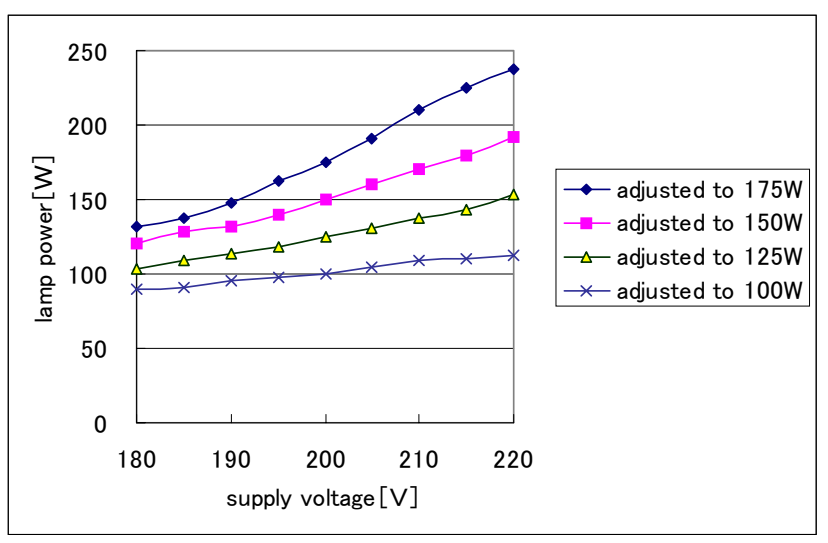

図 6 電源電圧に対するランプ電力の特性

Fig. 6. Characteristics of lamp power for voltage.

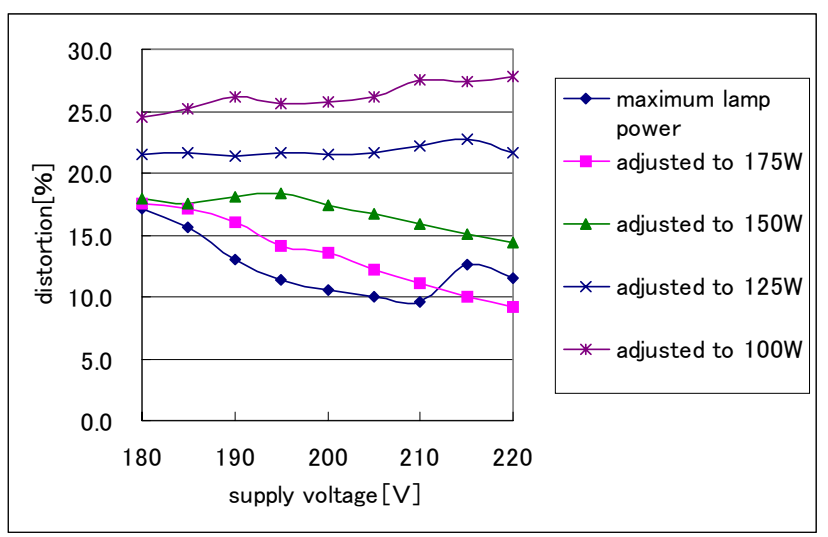

図 7 電源電圧に対する電源電流のひずみ率の特性

Fig. 7. Characteristics of distortion for voltage.

セッティングする。実験方法は, 前の実験と同様にまずラ ンプ電力が最大になるように導通角を調整して，ランプが 安定状態になったら電圧を $180 \mathrm{~V}$ から $220 \mathrm{~V}$ まで $5 \mathrm{~V}$ 間隔で 変動させていき, そのときの電力や力率, 電源電流のひず み率を調べる。さらに, ランプ電力を $175 \mathrm{~W}, 150 \mathrm{~W} ， 125 \mathrm{~W}$, 


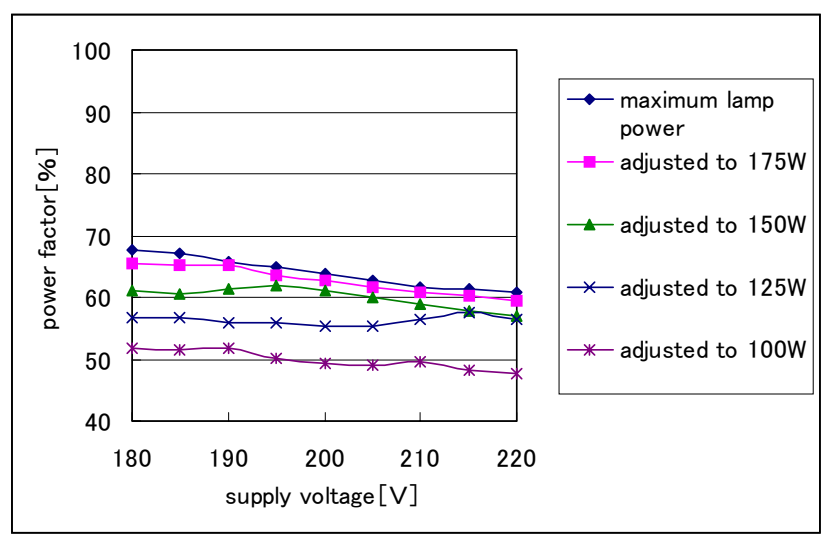

図 8 電源電圧に対する力率の特性

Fig. 8. Characteristics of power factor.

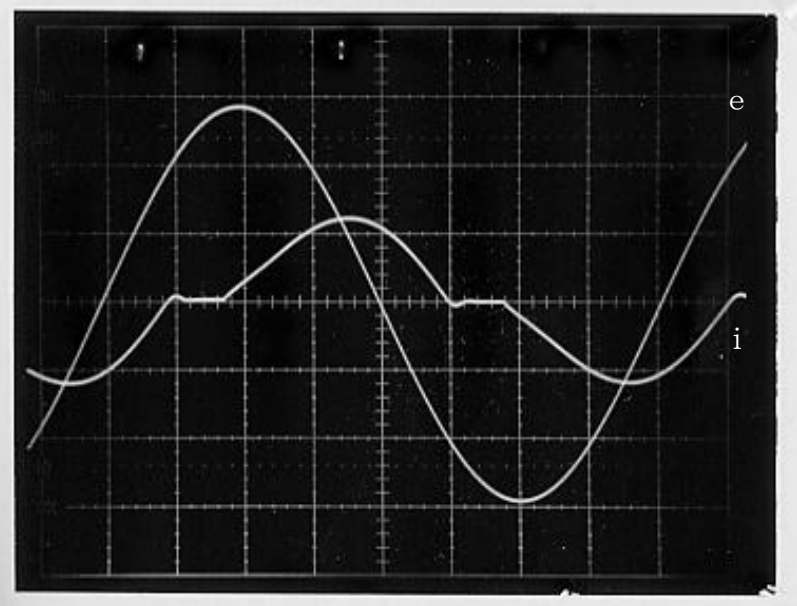

(a) Adjusted to $100 \mathrm{~W}$

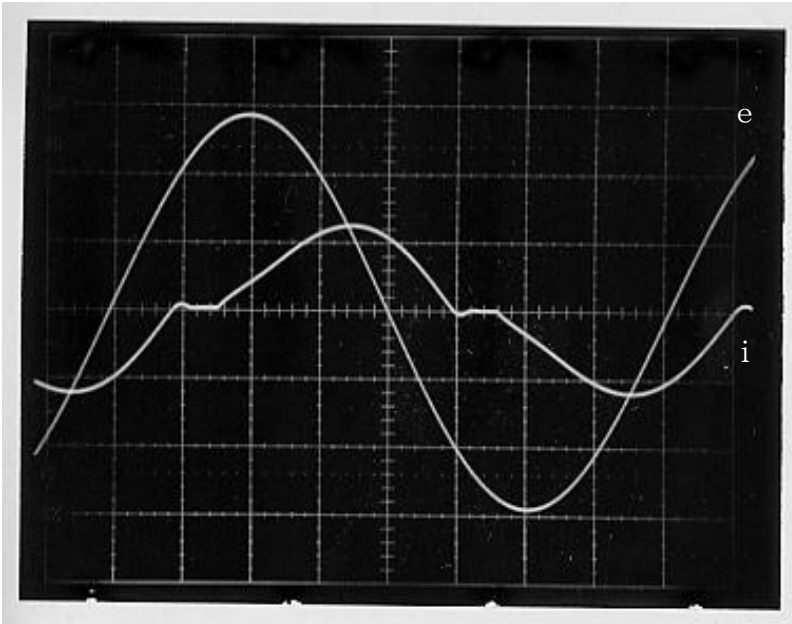

(b) Adjusted to $125 \mathrm{~W}$

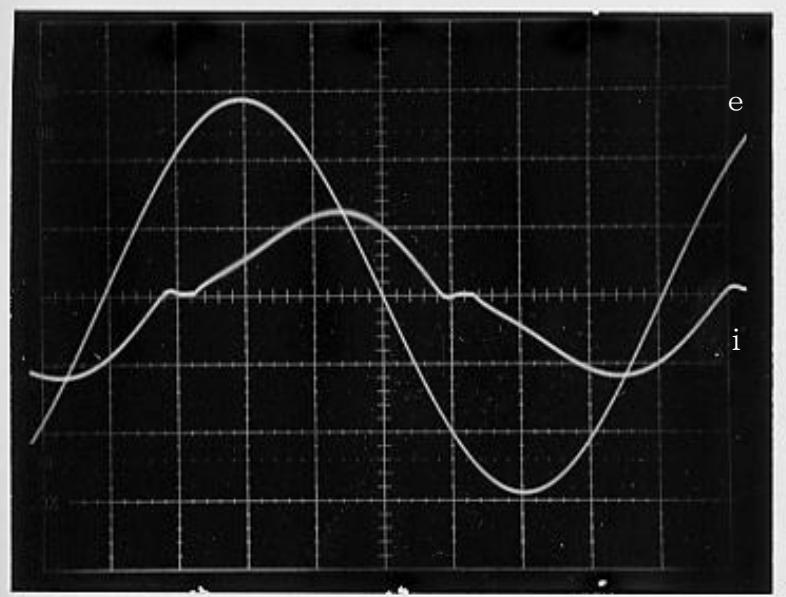

(c) Adjusted to $150 \mathrm{~W}$

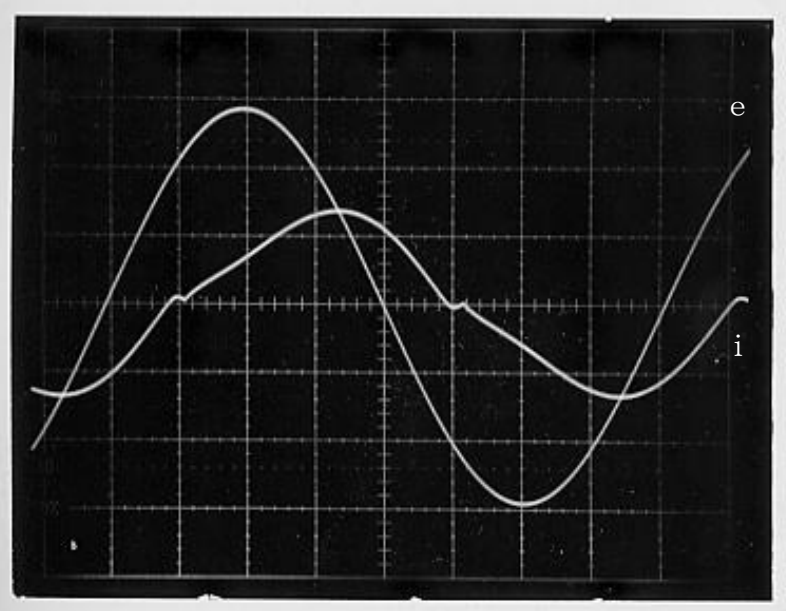

(d) Adjusted to $175 \mathrm{~W}$

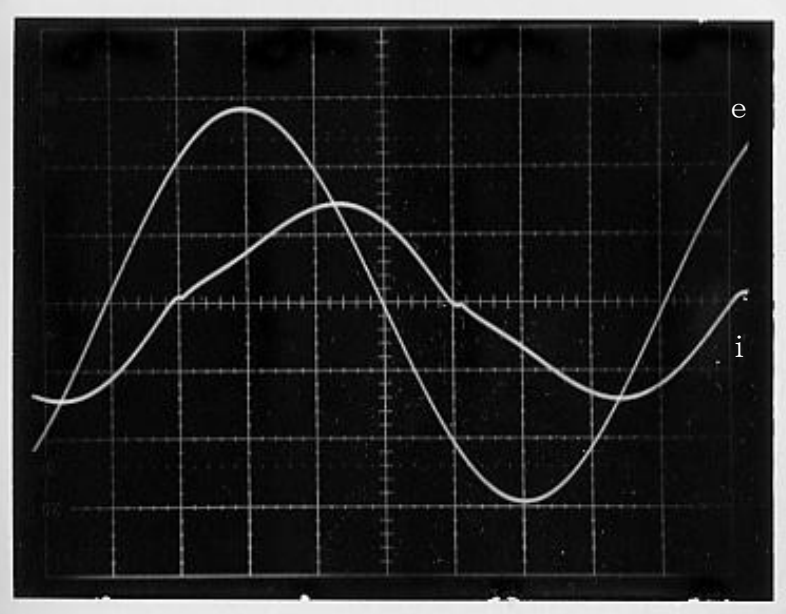

(e) Maximum lamp power

$e: 100 \mathrm{~V} / \operatorname{div}, \quad i: 2 \mathrm{~A} / \operatorname{div}$

図 9 電源電圧と電流の波形

Fig. 9. Waveforms of voltage and current of power source. 
$100 \mathrm{~W}$ に調整して電源電圧の変動に対するランプ電力の変 動や力率, 電源電流のひずみ率を求める。

図 6 は, 電力変動低減形連続調光式点灯回路の電源電圧 の変動に対するランプ電力の変化を示したものであり, 図 7 が電源電流のひずみ率の変化，図 8 が力率の変化を示した ものである。さらに, 図 9 の写真は電源電圧 $200 \mathrm{~V}$ における 電源電圧・電源電流の波形を表したものである。

図 6 から電力変動が低減されていることが明らかにわか る。しかし，図 7, 図 9 から電源電流のひずみ率が非常に大 きくなっている。また，図 8 から力率は 47\%から 67\%の範 囲にあり，非常に悪いことがわかる。

175W の調光時において $\pm 50 \mathrm{~W}$ の変動が生じているのは, 光量が強すぎることで，光センサーである $\mathrm{Cds}$ の照度一抵 抗特性が飽和状態に近くなっており，充分な制御が成され ていないことによる。照度一抵抗特性の広い $\mathrm{Cds}$ を用いる ことで変動をさらに低減化することが可能である。

$\langle 3 \cdot 3\rangle$ 電力変動低減形連続調光式点灯回路にバイパス 回路を設けた場合図 3 に示したように，高調波電流を バイパスさせるバイパス回路を設けた回路にて実験を行 う。バイパス回路用の安定器巻線の容量は, 連続調光式点 灯回路と同様に $0.26 \mathrm{H}$ を使用する。また, この安定器巻線 の電源側に近い方から $1 / 5$ のタップ位置にバイパス回路を 設ける。バイパス回路の回路定数は前の調光回路と同様に シミュレーションで求められた $\mathrm{Lb}, \mathrm{Cb}$ の值を参考とした。 前実験と同様に最適值として $75 \mathrm{mH}$ のチョークコイル Lb と $19.9 \mu \mathrm{F}$ のコンデンサ $\mathrm{Cb}$ を使用した。

この回路構成で, 前述のようにそれぞれの導通角におい て電源電圧の変動に対するランプ電力の変動や力率, 電源 電流のひずタ率を求めていく。

図 10 は, 電力変動低減形連続調光式点灯回路にバイパス 回路を設けた場合の電源電圧の変動に対してランプ電力の 変化を示したものである。図 11 が，電源電流のひずみ率の 変化, 図 12 が力率の変化を示したものである。さらに, 図 13 の写真は電源電圧 $200 \mathrm{~V}$ における電源電圧・電源電流の 波形を表したものである。

図 11 から電源電流のひずみ率のほとんどが 6\%以下に低 減されており，また図 12 から力率は 75\%からほぼ100\%に 改善されていることがわかる。

〈3.4〉 ランプ電力および電源電流のひずみ率に関する 考察連続調光式点灯回路と電力変動低減形連続調光式 点灯回路のそれぞれにおいて，バイパス回路を設けた場合 の電源電圧の変動に対するランプ電力の変動を図 14 に示 す。さらに，バイパス回路あり，なしのそれぞれのときの 電源電流のひずみ率を同じく図 14 に示す。図 14 は, 調光 を最大にしたとき， $175 \mathrm{~W}$ に調光，150W に調光，125W に 調光, $100 \mathrm{~W}$ に調光した $5 つ$ 条件において，それぞれ電源 電圧を $180 \mathrm{~V} \sim 220 \mathrm{~V}$ までを $5 \mathrm{~V}$ 間隔で変動させたときのラン プ電力および電源電流のひずみ率の特性を比較したもので ある。また，図 15 の写真は，バイパス回路を設けた場合の $175 \mathrm{~W}$ 調光時の電源電圧の変化に対する電源電圧と電源電

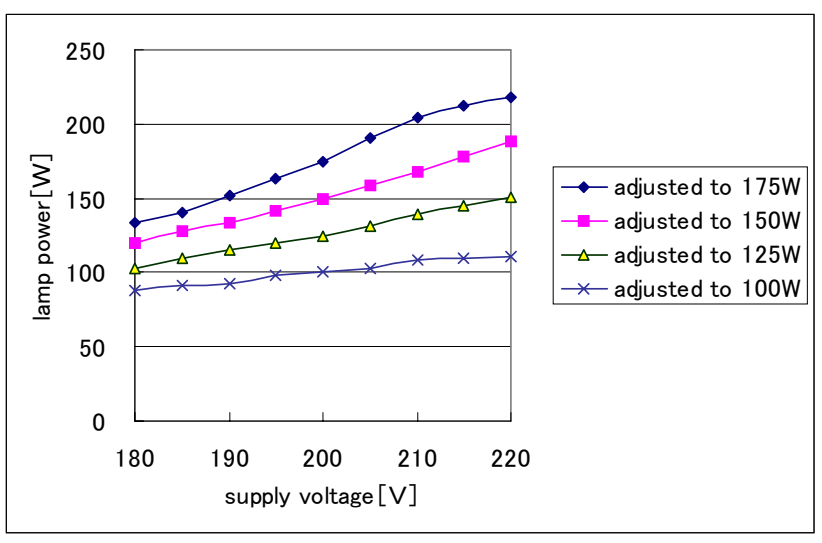

図 10 電源電圧に対するランプ電力の特性

Fig. 10. Characteristics of lamp power for voltage.

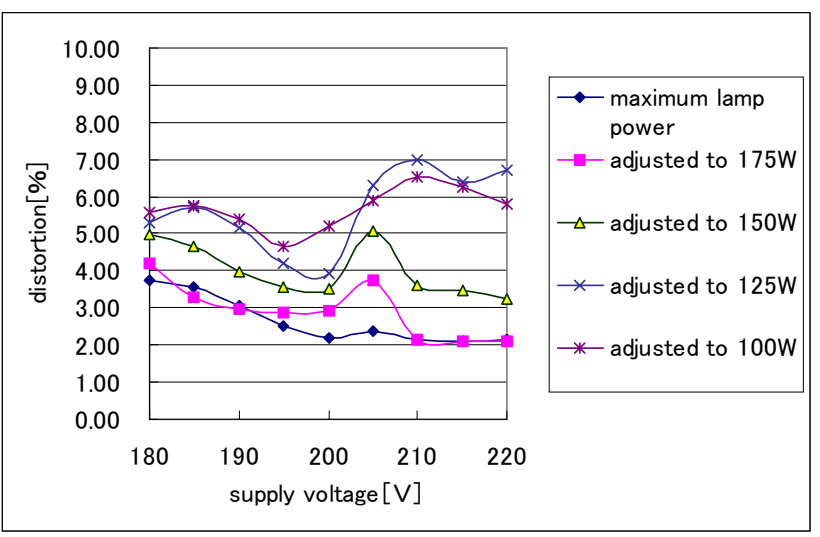

図 11 電源電圧に対する電源電流のひずみ率の特性

Fig. 11. Characteristics of distortion for voltage.

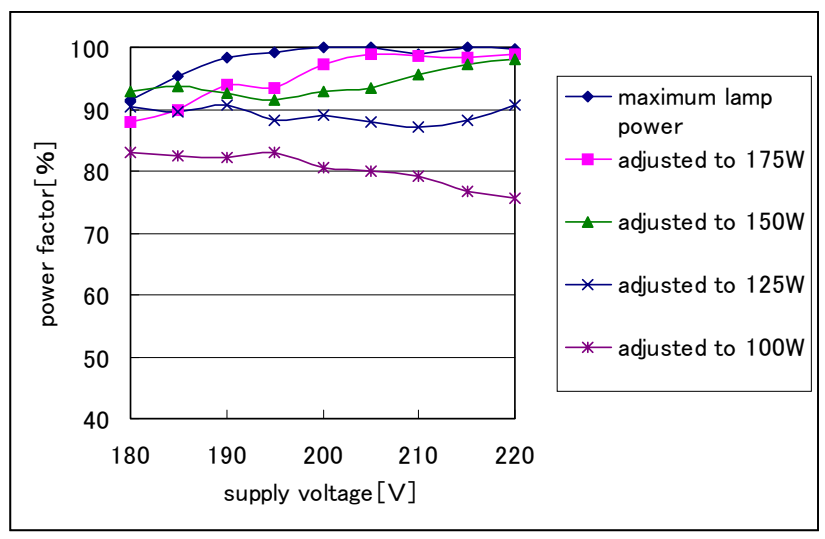

図 12 電源電圧に対する力率の特性

Fig. 12. Characteristics of power factor.

流の波形を表したものである。

まず連続調光式点灯回路と電力变動低減形連続調光式点 灯回路のランプ電力変動結果を比較する。グラフの傾きか ら, 調光状態においては電源電圧の変動に対するランプ電 力の変動は明らかに低減化されていることがわかる。ただ 


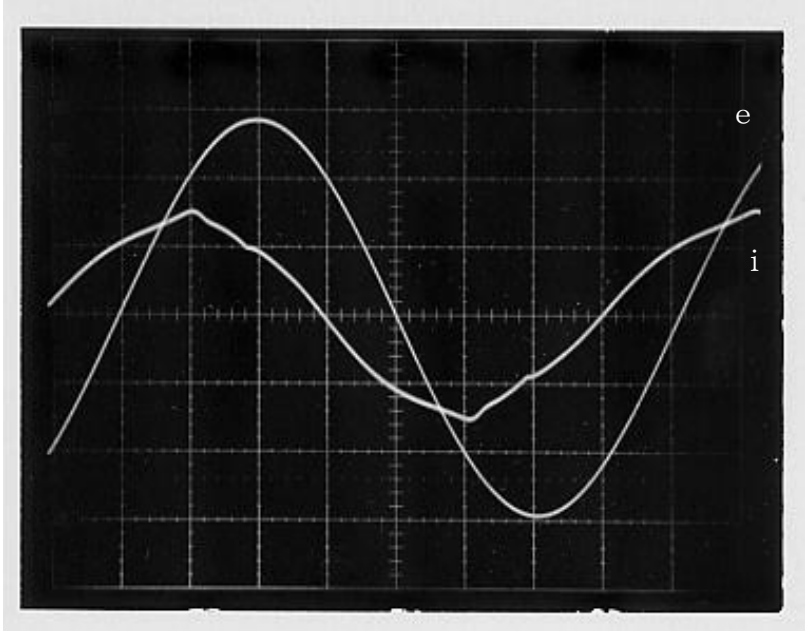

(a) Adjusted to $100 \mathrm{~W}$

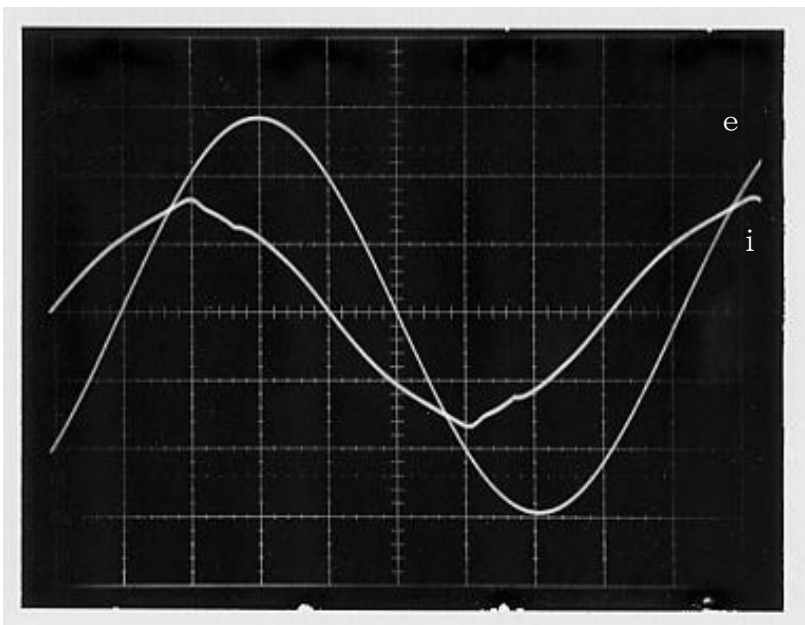

(b) Adjusted to $125 \mathrm{~W}$

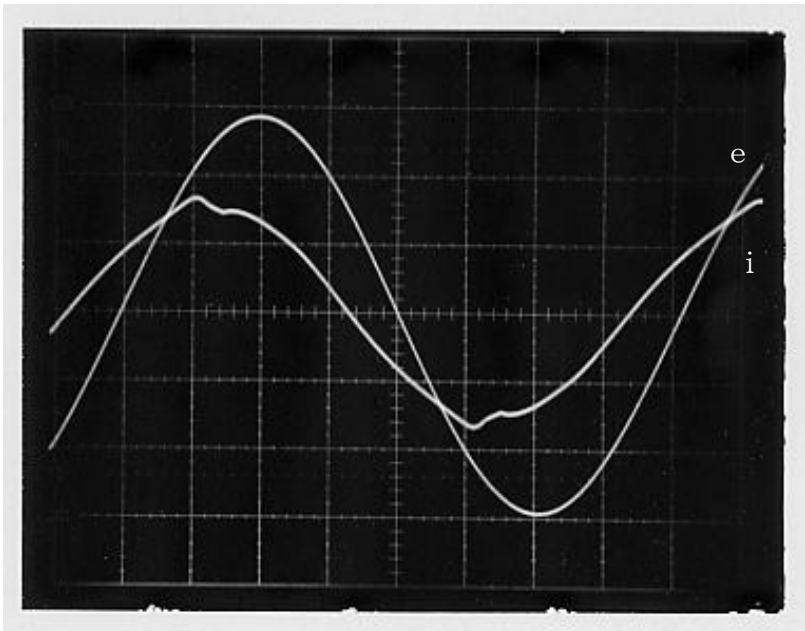

(c) Adjusted to $150 \mathrm{~W}$

し，導通角をほぼ $180^{\circ}$ の最大にしたときは回路の特性上制 御範囲がほとんど無いために制御が効いていない。光量補 正制御回路は，電源電圧の上昇によりランプ電力が上昇す ると導通角を小さくして上昇したランプ電力を下げる方向 に制御が働く。また逆に電源電圧の低下によりランプ電力

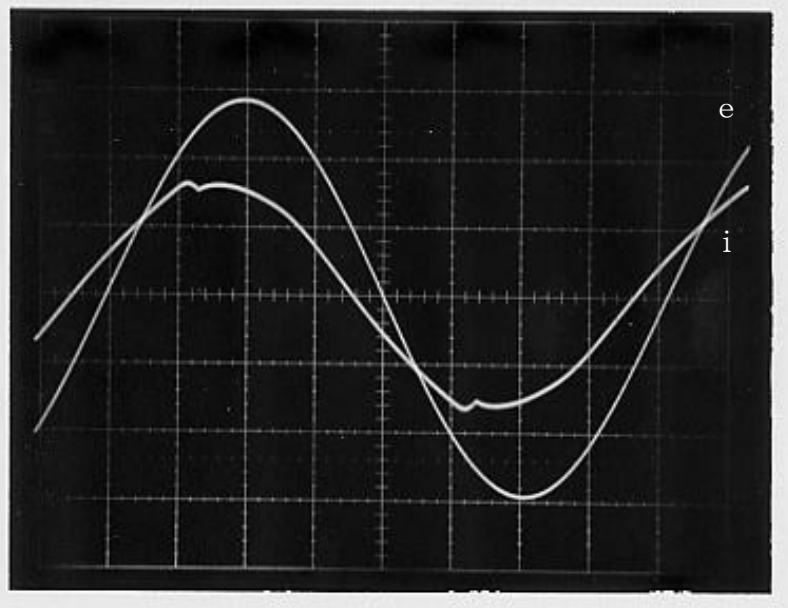

(d) Adjusted to $175 \mathrm{~W}$

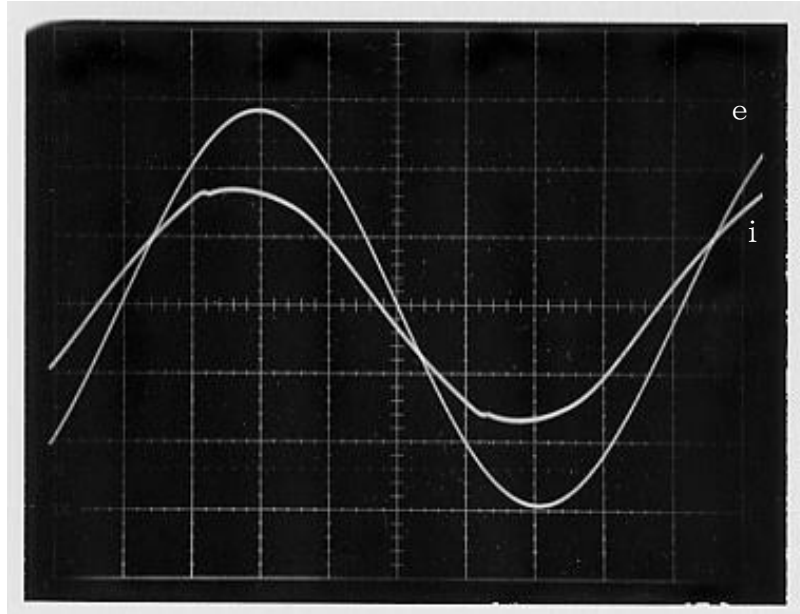

(e) Maximum lamp power

$e: 100 \mathrm{~V} / \operatorname{div}, i: 1 \mathrm{~A} / \operatorname{div}$

図 13 電源電圧と電流の波形

Fig. 13. Waveforms of voltage and current of power source.
が下がると導通角を大きくして下がったランプ電力をもと に補正しようと制御が働く。このため, 導通角が大きい場 合においては，ランプ電力の上昇に対して導通角を小さく して制御することが出来るが，電源電圧が低下してランプ 電力が下がった場合においては、導通角が $180^{\circ}$ 以上にはな 


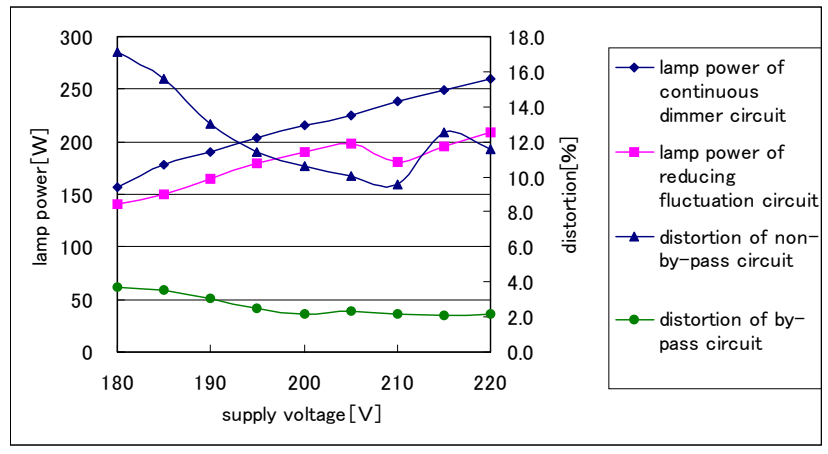

(a) Maximum lamp power

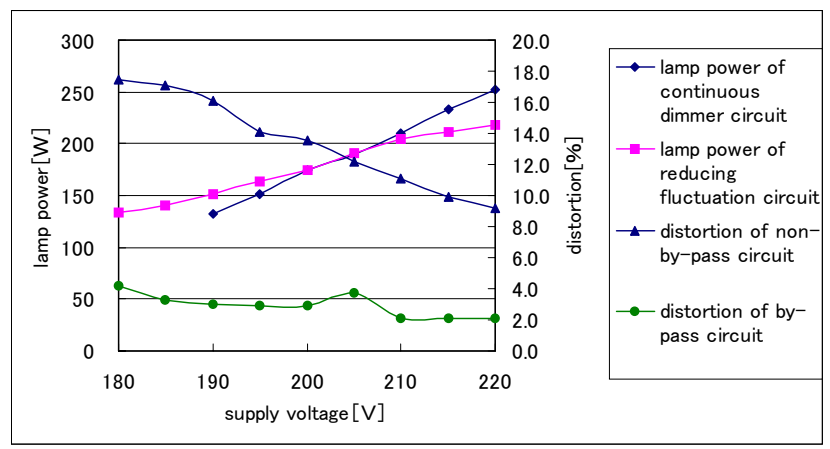

(b) Adjusted to $175 \mathrm{~W}$

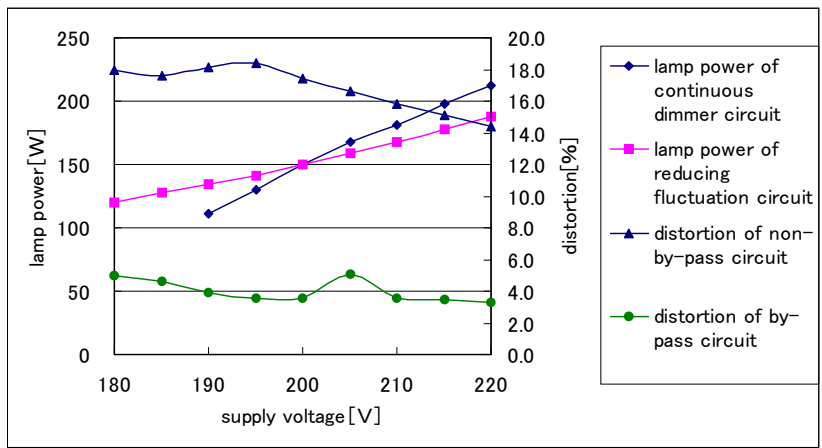

(c) Adjusted to $150 \mathrm{~W}$

らないためランプ電力を上げる方向に制御出来ない。今後 の研究課題でもある。

$100 \mathrm{~W}$ 調光状態においては，67W の電力変動が $11 \mathrm{~W}$ の変 動にまで低減化されている。100W から $175 \mathrm{~W} の$ 各調光電力 值の変動を平均して 50\%程度の低減化が可能である。さら に連続調光式点灯回路の電源電圧の変動特性では，電源電 圧が定格電圧より下降するとランプ電力が急激に下がり， 導通角が小さい程，点灯状態を維持することが困難となり 立ち消えを発生してしまう。図 14 の連続調光式点灯回路の 実験結果において定格電圧より低下している場合のランプ 電力実験データが得られていないのはこのためである。し かし, 電力変動低減形連続調光式点灯回路はランプ電力が 低下し光量が減少するとそれを補正するため導通角を大き くしてランプ電力を増加させる。よって電源電圧の広範囲

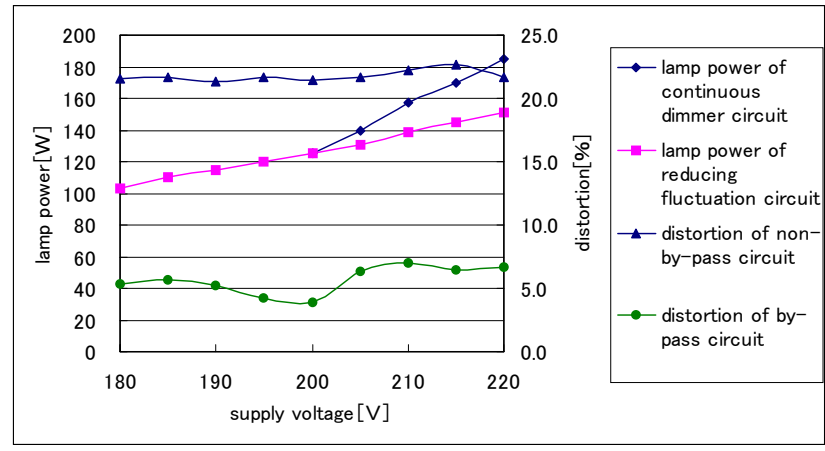

(d) Adjusted to $125 \mathrm{~W}$

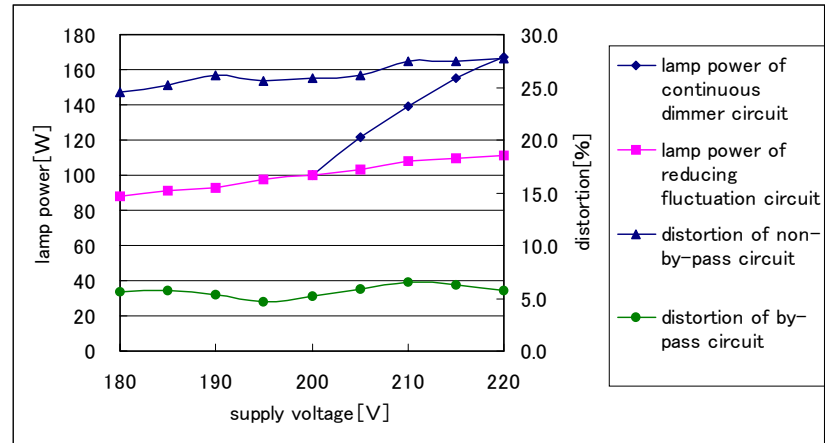

(e) Adjusted to $100 \mathrm{~W}$

図 14 電源電圧の変動に対するランプ電力の変動と 電源電流のひずみ率の比較

Fig. 14. Characteristics of lamp power and distortion for voltage.

な変動に対してもランプの点灯状態を常に維持する方向に 光量補正制御が働くため, 安定した連続点灯が可能となる。

次に電源電流のひずみ率について考察する。電力変動低 減形連続調光式点灯回路は, 制御回路から発生する高調波 成分も加わるため電源電流のひずみ率が大きくなる。この 改善方法として, 著者らがさきに報告している安定器巻線 途中からのバイパス回路を用いた電流波形の一改善法を適 用する。

電力変動低減形連続調光式点灯回路のみの場合と電力変 動低減形連続調光式点灯回路にバイパス回路を設けた場合 の実験結果を電源電流のひずみ率等に関して比較してみる。

図 14 より, 電力変動低減形連続調光式点灯回路のみの場 合は，電源電流のひずみ率において $10 \%$ 以上，最大 $28 \%$ と 電源の電流波形が非常に悪い。 


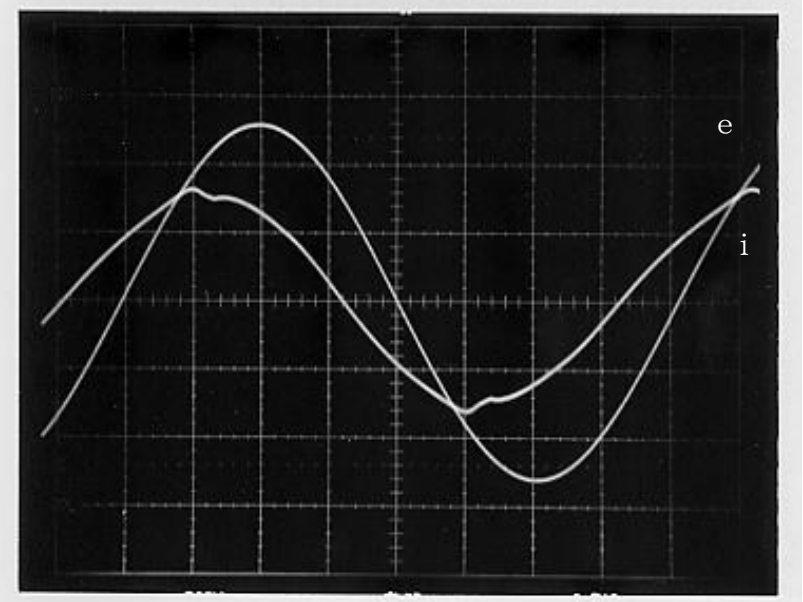

(a) Supply voltage $180 \mathrm{~V}$

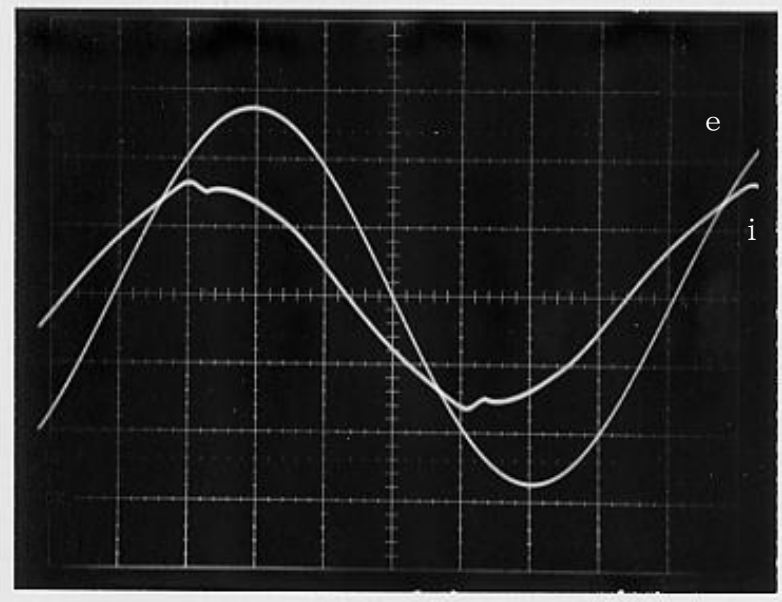

(b) Supply voltage $190 \mathrm{~V}$

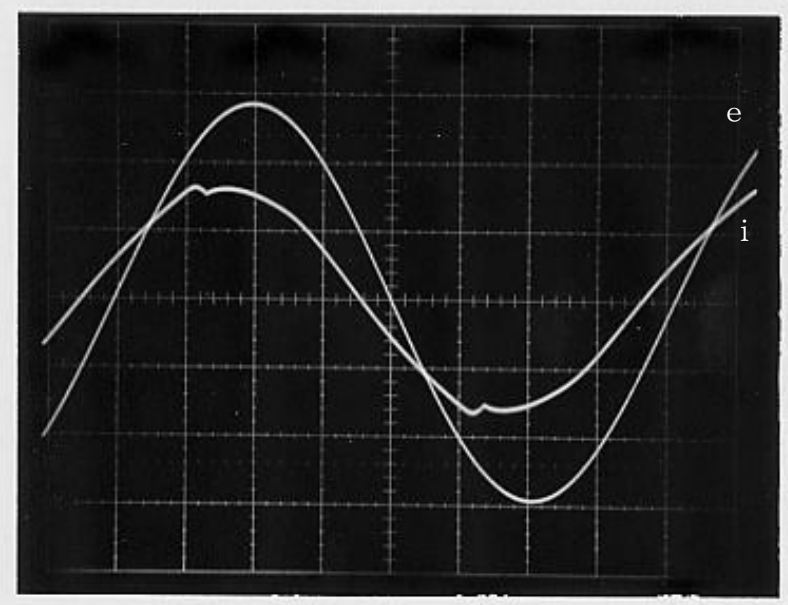

(c) Supply voltage $200 \mathrm{~V}$

電力変動低減形連続調光式点灯回路にバイパス回路を設 けた場合，電源電流のひずみ率のほとんどが $6 \%$ 以下に押え られていることが分かる。したがって，バイパス回路を設 けることにより, 電源電流のひずみ率を大きく改善するこ とができる。さらに, 力率も図 8 と図 12 の比較から, 前述

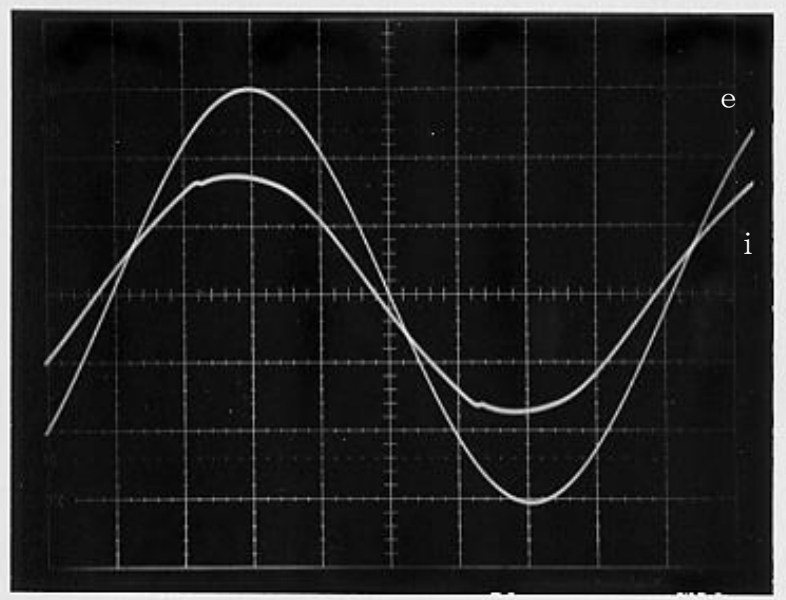

(d) Supply voltage $210 \mathrm{~V}$

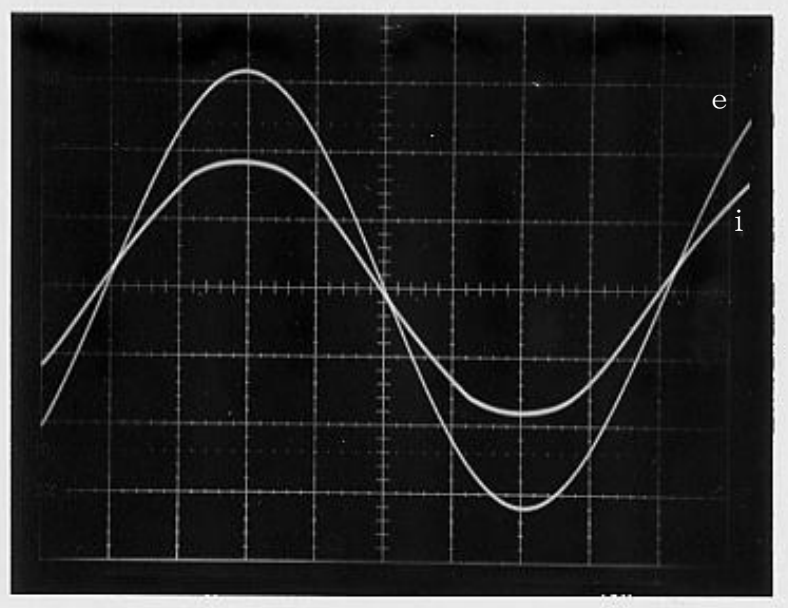

(e) Supply voltage $220 \mathrm{~V}$

$$
e: 100 \mathrm{~V} / \operatorname{div}, i: 1 \mathrm{~A} / \operatorname{div}
$$

図 15 電源電圧と電流の波形

Fig. 15. Waveforms of voltage and current of power source.
したように 47\%から 67\%の範囲にあったものが，バイパス 回路を設けることにより，75\%からほぼ 100\%にまで大きく 改善された。図 9 と図 15 の比較からも高調波電流が低減さ れ，力率が改善されてていることが明らかである。

また, 電源電圧の変動に対するランプ電力の変化におい 
ては，実験結果を見る限りバイパス回路を設けたときが最 も変動が少ないことがわかった。バイパス回路を設けたこ とにより，ランプの基本波インピーダンスが小さくなるた め, 安定器巻線の自己インダクタンスの值を定格より大き くした。そのことでランプ電圧が低下し，同等のランプ電 力を得るに必要なランプ電流の基本波が増加したため, 導 通角による電流の制御が, 効果的に働いたものと考えられ る。

\section{4. まとめ}

筆者らは高圧水銀ランプ電力低減形連続調光式点灯回路 について検討した。本研究で次の事項が明らかになった。

（1）連続調光式点灯回路において, 光センサーによる電 力変動を補正する制御回路を付加することにより, 電源電 圧の変動によるランプ電力の変動を $100 \mathrm{~W}$ 調光においては $17 \%$, 各調光電力值の変動を平均して $50 \%$ 程度まで低減で きた。さらに, 電源電圧が定格電圧以下となった場合も, 点灯状態を維持する方向に補正制御が働くため, 立ち消え の発生を抑え安定した連続点灯を可能とした。

（2）制御回路を安定器巻線のランプ側に置くことで, 高 調波を低減するバイパス回路が制御回路も含めた状態で適 用される。すなわち, 連続調光式点灯回路の電流波形と力 率の一改善法(2)を適用し, 適正值を求めた回路定数のバイパ ス回路を設けることで力率と電源電流のひずみ率の改善を 可能とした。

以上のように, 光量補正制御回路を付加した定格ランプ 電力 $200 \mathrm{~W}$ の連続調光式点灯回路において電源電圧の変動 に対するランプ電力の変動低減と安定した連続運転を実現 した。また, 連続調光式点灯回路の電流波形と力率の一改 善法(2)を適用した回路定数によるバイパス回路を設けるこ とにより, 力率の改善と高調波電流低減化を実現した。な お, 各種定格ランプ電力の連続調光式点灯回路においても 光量補正制御回路を付加することにより, 電源電圧の変動 に対するランプ電力の変動低減と安定した連続運転が可能 と思われる。

(平成 14 年 9 月 12 日受付, 平成 15 年 2 月 27 日再受付)

\section{文献}

(1) M.Iemura, T.Nakamura, M.Kurozumi, and J.Yamaguchi : "Discussions of same phase high-pressure mercury lamp operating circuits", T. IEE Japan, Vol.115-A, No.11, pp.1062-1071 (1995-11) (in Japanese)

家村道雄・中村 格・黒住正明・山口純一:「高圧水銀ランプ同相形 点 灯回路の考察」, 電学論 A, 115, No.11, pp.1062-1071 (1995-11)

(2) M.Iemura, H.Sakamoto, M.Kurozumi, and J.Yamaguchi : "Method to improve Current Wave Forms and Power Factor in the Continuous Dimmer Circuit for High-Presssure Mercury Discharge Lamps", J. Illum. Engng. Inst. Jpn, Vol.80 (1996) (in Japanese) 家村道雄・坂本 浩・黑住正明・山口純一:「高圧水銀ランプ 連続 調光式点灯回路の電流波形と力率の一改善法」, 照明学誌, Vol.80 (1996)

黒 住 正 明 （非会員）1963 年 10 月 17 日生まれ。1986 年 3 月宮崎大学工学部電気工学科卒業。同年新日本

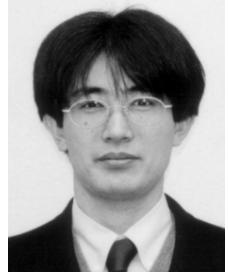
製鐵(株)入社。1987 年九州松下電器(株)入社, 電子制御機器の開発に従事。1991 年〜2003 年 宮崎工業高校, 延岡工業高校(情報技術科主任, 教務主任)。2003 年宮崎県教育研修センター指 導主事, 現在に至る。放電ランプ点灯回路の高 調波電流低減化に関寸る研究に従事。照明学 会, 電気設備学会会員。

家 村 拓 雄 (非会員) 1971 年 7 月 1 日生まれ。1996 年 3

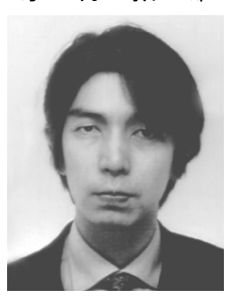
月熊本大学工学部電気情報工学科卒業。同年 (株)九電工入社。現在, 九電工東京支店勤務。

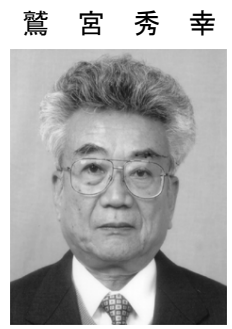

家 村 道 雄

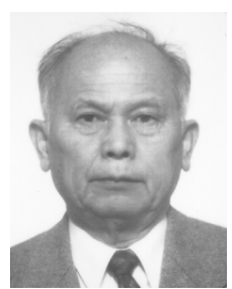

（正員） 1937 年 1 月 4 日生まれ。1961 年 3 月 鹿児島大学工学部電気工学科卒業。1964 年 92 年宮崎県立日向工業高校, 都城工業高校, 宮崎 工業高校(生徒指導主事, 電気科主任)。同年 4 月熊本工業大学(現 崇城大学)講師。1997 年 4 月同教授となり, 現在に至る。この間, 放電ラ ンプ点灯回路の高調波電流低減化に関寸る研 究に従事, 工学博士。1981 年オーム奨学賞, 1992 年 6 月第 3 回電気設備学会賞受賞。照明学会, 電気設備学会会員。 